\title{
A Study on the Serum Immunoglobulin Levels in Pulmonary Tuberculosis Patients
}

\author{
Rohini K., Srikumar P. S., and Mahesh Kumar A.
}

\begin{abstract}
Tuberculosis is a severe bacterial infection caused by Mycobacterium tuberculosis. In the recent years, studies on the immunological diagnosis of tuberculosis have become advancing. In this study, forty patients diagnosed with tuberculosis on the basis of history, clinical examination, chest radiography, sputum examination and related laboratory parameters were recruited from The Institute of Thoracic Medicine, Chennai, India and were compared with age and sex matched healthy volunteers $(n=35)$. The Serum immunoglobulins IgA, IgM, IgE levels were determined in 40 patients with pulmonary tuberculosis. IgA, IgM, IgE, levels were found to be increased significantly $(p<0.001)$ when compared with normal healthy volunteers. The rise of IgA, IgM, IgE levels in patients with tuberculosis may be interpreted as humoral response to mycobacterial antigens.
\end{abstract}

Index Terms-Tuberculosis, IgA, IgM, IgE.

\section{INTRODUCTION}

About one third of the world population is infected with Mycobacterium tuberculosis, the causative organism of tuberculosis [1], [2]. The immunology of tuberculosis and the significance of delayed hypersensitivity as protective immunity have been extensively studied in the light of modern sophisticated immunological techniques [3], [4]. The clinical usefulness of detection of serum immunoglobulin IgG and IgM antibodies have been reported in tuberculosis and other pulmonary diseases [5]. Host humoral response to mycobacterial antigens depends upon the production of different types of antibodies (immunoglobulins) and is the expression of the functional capacity of immunoglobulin producing cells [4]. In the present study, we evaluated the serum immunoglobulin levels to study the humoral response in patients of pulmonary tuberculosis.

\section{MATERIALS AND MethodS}

The study was conducted on 40 pulmonary tuberculosis patients (25-75 yrs) recruited from The Institute of Thoracic Medicine, Chennai, India. . Age and sex matched healthy volunteers $(n=35)$ were used as control subjects. Blood samples were collected with the consent of each patient and processed for serum preparation.

Manuscript received June 24 2012; revised July 30, 2012.

Rohini K. is with the Unit of Biochemistry, Faculty of Medicine AIMST University (e-mail: rohinik23@gmail.com).

Dr. Srikumar P. S. is with the Unit of Psychiatry, Faculty of Medicine AIMST University (e-mail: gooddoc15@gmail.com).

Dr. Mahesh Kumar A. is with the Madras Medical Mission Hospital, Mogappair, Chennai.
The diagnosis of tuberculosis was performed using Ziehl-Neelsen staining method for Acid-fast Microscopy (AFM) [6] and culture for growth of the organism on Lowensterin-Jensen (LJ) medium [7]. The patients were also tested for radiographic abnormalities and various other laboratory parameters. The levels of $\operatorname{IgM}$ and $\operatorname{IgA}$ were measured based on the methods of Geiger et al [8] and Whicher et al [9]. Briefly, diluted serum sample was mixed with specific human antiserum for $\operatorname{IgM}$ or $\operatorname{IgA}$ to form precipitate and the turbidity was measured at $340 \mathrm{~nm}$ in a semi auto analyzer. The level of IgE was measured by ELISA technique as described by Witing et al. [10] and Johansson et al. [11]. After quenching with acid, specific antibody for human $\operatorname{IgE}$ conjugated with horse radish peroxidase was added to serum sample followed by the addition of orthophenylene diamine phosphate and the colored product formed was measured at $450 \mathrm{~nm}$.

\section{Statistical Analysis}

The SPSS software package (Version 10) for used for all statistical analysis. All values were represented as mean \pm SD . Statistical analysis was performed by student's $t$-test.

\section{RESUlTS}

The findings of the serum immunoglobulins in tuberculosis patients and in normal healthy volunteers are represented in the Table I. The levels of IgM, IgA and IgE levels were compared with normal healthy volunteers and was found to be increased significantly $(p<0.001)$ (Fig. 1) The level of IgA was found to be significantly increased in tuberculosis patients. There was a significant elevation in the levels of $\operatorname{IgM}$ and $\operatorname{IgE}$ when compared to normal healthy volunteers.

\section{TABLES AND FIGURES}

TABLE I: CLINICAL CHARACTERISTICS OF PATIENTS.

\begin{tabular}{|c|c|}
\hline Clinical characteristics & No. of subjects \\
\hline Total Number & 40 \\
\hline Age & $25 \pm 75$ years \\
\hline Sex & Male - 35; Female - 5 \\
\hline \multicolumn{2}{|l|}{ Clinical Signs } \\
\hline Cough & 40 \\
\hline Fever & $25-30$ \\
\hline Weight loss & 40 \\
\hline Night sweats & $25-30$ \\
\hline
\end{tabular}




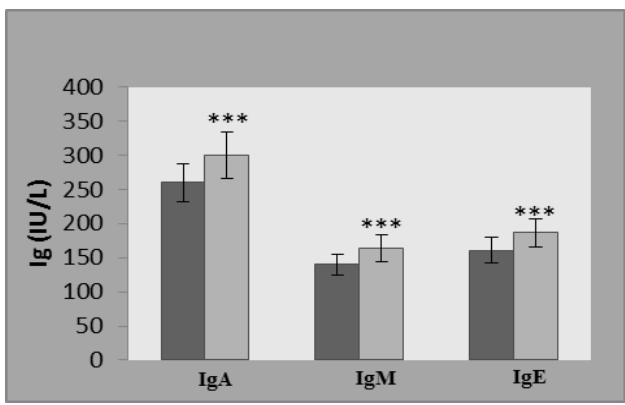

Fig. 1. Serum IgA, IgM and $\operatorname{IgE}(\mathrm{IU} / \mathrm{L})$ in normal volunteers and tuberculosis patients.

\section{DISCUSSION}

Pulmonary tuberculosis is diagnosed based upon the clinical, radiological and bacteriological evidence; however serological diagnosis is considered more significant. Studies have shown that a high proportion of patients with tuberculosis have significantly increased levels of antibody to mycobacterium tuberculosis by using "enzyme-linked immunosorbant assay" [12]. Our present study shows that the values of $\operatorname{IgA}, \operatorname{IgM}, \operatorname{IgE}$ were found to be significantly increased in tuberculosis patients when compared with normal healthy volunteers. Jha et al have reported that no definite relation of various levels of immunoglobulins with increasing severity of disease [13]. An increase in the level of $\operatorname{IgA}$ in relation to the extent of disease was reported by Skvor et al. [14]. Reports on total IgG and IgA levels in patients of pulmonary tuberculosis was interpreted as humoral response to mycobacterial antigens while Grange et al [12] observed no correlation between the levels of various immunoglobulins and the antimycobacterial antibody levels. Jha et al [13] suggested that insignificant increase in IgM could be attributed to the fact that more than $80 \%$ of their cases had cavitary lesions signifying post-primary disease and the patients exhibited a secondary response by synthesizing more IgG

\section{CONCLUSION}

It has been clear that TB patients produce antibodies against more than one antigen and, consequently, a wide spectrum of humoral responses exists in these patients. In conclusion, the increase in the levels of $\operatorname{IgA}, \operatorname{IgM}, \operatorname{IgE}$ levels pulmonary tuberculosis patients may be interpreted as humoral response to mycobacterial antigens. However, keeping in mind the contradictory findings by different researchers, further studies need to be conducted to assert the role of these immunoglobulins as potential markers in tuberculosis diagnosis.

\section{CONFLICT OF INTERESTS}

The authors stated that there are no conflicts of interest regarding the publication of this article. The study protocol was approved by the Institutional ethics committee and was carried out in accordance with the principle of Declaration of Helsinki. Informed consent was obtained from all the subjects.

\section{REFERENCES}

[1] World Health Organisation. Tuberculosis fact sheet. [Online] Available: http://www.who.int/gtb/publications/factsheet/index.htm.

[2] World Health Organisation, "Treatment of tuberculosis: Guidelines for national programmes," Geneva 2003, pp. 11-15.

[3] V. K. Jain, H. S. Bishnoi, O. P. Beniwal, and S. N. Misra, "Immunoglobulin profile in pulmonary tuberculosis," J Postgrad Med 1984, vol. 30, no. 80.

[4] G. P. Youmans, "Editorial-Relations between delayed hypersensitivity and immunity in tuberculosis," Amer. Rev. Resp. Dis., vol. 111, pp. 109-118, 1975.

[5] W. B. Selma, H. Harizi, and J. Boukadida, "Immunochromatographic IgG/IgM test for rapid diagnosis of active tuberculosis," Clin Vaccine Immunol. 2011 December; vol. 18, no. 12, pp. 2090-2094.

[6] T. Talat, B. M. Bhatti, and M. Yaqoob, "Comparative efficacy of different laboratory techniques used in diagnosis of tuberculosis in human population," J. Medical Sci., vol. 2, pp. 137-144, 2002

[7] P. M. Fatolahzadeh, A. Bahador, H. Peeri-Dogaheh, M. Y. Alikhani, and R. Radmanesh-Ahsani, "Evaluation of different primer sets for the rapid diagnosis of tuberculosis," Pak. J. Biol. Sci., vol. 10, pp. 107-111, 2007

[8] H. Geiger and P. Hoffman, "Quantitaive immunological determination of 16 different blood proteins in 260 normal children," aged 0 to 15 years. Z. Kinderheilkd, vol. 109, pp. 22-40, 1970.

[9] J. T. Whicher, C. P. Price, and K. Spencer, "Immunonephelometric and immunoturbidometric assays for proteins," Crit. Rev. Clin. Lab. Sci., vol. 18, pp. 213-260, 1983.

[10] H. J. Wittig, "Age related serum immunoglobulin E levels in healthy subjects and in patients with allergic disease," J.Allergy Clin. Immunol., vol. 66, pp. 305-313, 1980.

[11] S. G. Johansson, H. H. Bennich, and T. Berg, "The clinical significance of IgE. Prog,” Clin. Immunol., vol. 1, pp. 157-181, 1972.

[12] J. M. Grange, J. Gibson, E. Nassau, and T. Kardjito, "Enzyme linked immunosorbant assay: A study of antibodies to mycobacterium tuberculosis in the IgG, IgA, IgM classes in T.B.," Sarcoidosis and Crohn's Disease. Tubercle. vol. 61, pp. 145-152, 1980.

[13] V. K. Jha, B. K. Bajpai, and R. M. Gupta, "Levels of serum immunoglobulin in pulmonary tuberculosis patients," Ind. J. Chest Dis., vol. 16, pp. 361-367, 1974.

[14] J. Skvor, L. Trnka, and Z. Kugukovova, "Immunoprofile studies in patients with pulmonary tuberculosis. II-Correlation of levels of different classes of immunoglobulins and specific antibodies with the extent of tuberculosis," Scand. J. Resp. Dis., vol. 60, pp. 168-171, 1979

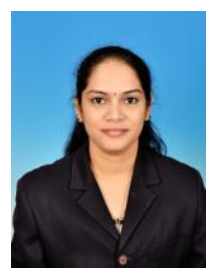

Rohini K. was born on $23^{\text {rd }}$ of June 1980, Chennai, India. She is currently pursuing her PhD in Biochemistry at Banasthali University, India. She holds Masters degrees in Biochemistry and Clinical Microbiology with an M.Phil in Life Science, besides, a Bachelor's in Education and PG Diploma in Bioinformatics, Medical Lab Technology and Forensic Science. She is currently working as a Lecturer in the Unit of Biochemistry, Faculty of Medicine, AIMST University, Malaysia. She has published papers in the field of Bioinformatics and Biochemistry. She is also a Fellow Member in the Society of Biotechnology (FSAB) and Life member in Indian Association of Applied Microbiologists (IAAM), Society of Biological Chemists, India, (SBCI) \& Indian Academy of Forensic Science. Rohini has published 2 books titled: An Insilico Drug Design for Rheumatoid Arthritis and Drug Target Identification - G.bronchialis DSM 43247. 